\title{
Polylactide Used as Filment in 3D Printing - Part 1: FTIR, DRIFT and TG-DTG Studies
}

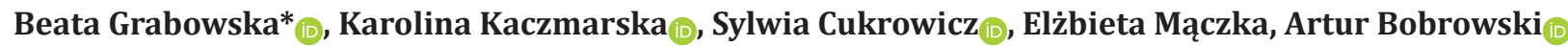

AGH University of Science and Technology, Faculty of Foundry Engineering, Reymonta 23, 30-059 Krakow, Poland

*e-mail: beata.grabowska@agh.edu.pl

(C) 2020 Authors. This is an open access publication, which can be used, distributed and reproduced in any medium according to the Creative Commons CC-BY 4.0 License requiring that the original work has been properly cited.

Received: 5 August 2020 /Accepted: 9 September 2020 /Published online: 30 September 2020

This article is published with open access at AGH University of Science and Technology Journals

\begin{abstract}
A short literature review was undertaken in terms of the structure, properties and applications of polymers, including those commonly used in 3D printing. The research part included the structural and thermal analysis of polylactide (PLA), which is an example of an extensively used polymer in the developing 3D technology. Special attention was paid to the comparison of structure and thermal stability of two different (from various producers) polylactide samples. The research, involving such analytical methods as infrared spectroscopy (FTIR) and diffuse reflectance infrared spectroscopy (DRIFT), allowed the comparison of the structure of the two PLA samples considered. The determination of the temperature range in which changes related to PLA thermodestruction occur was a result of the performed thermoanalytical research (DRIFT, TG-DTG). Thermal studies also allowed to establish the temperature range in which the material does not yet degrade, which is important in the context of future planned research work on polylactide modification to obtain the improvement of the thermal and mechanical properties of PLA-based materials. This research area will be described in the second part of the publication.
\end{abstract}

\section{Keywords:}

polylactide, 3D printing technology, thermal degradation, FTIR, TG-DTG

\section{INTRODUCTION}

3D printing technology is focused on the fabrication of wax patterns followed by final products being obtained in the lost wax casting process. It is especially useful in the production of small parts and assemblies used in miniaturized electronic devices and also in toy and jewellery manufacturing. Biomedical equipment, such as biocompatible implants, dental prosthetics, orthodontics and orthopedics are the most common medical applications of the 3D printing technique (Fig. 1) [1-10].

At present, a wide spectrum of materials is used for additive manufacturing in 3D printing technology. Their selection is closely related to the application of the achieved model/prototype. Contemporary materials mostly include polymers but also metals and ceramics.

While creating an illustrative visualization of the 3D planning models, cheap materials are considered, e.g. polyethylene (PE), acrylonitrile butadiene styrene (ABS) of technical purity. However, for the production of individualized elements intended to be introduced into the human body, biomaterials that meet specified requirements are needed. Biocompatibility, non-toxicity, and hypoallergenic properties are key to the successful application of implant materials. Biodegradable polymers such as polylactide (PLA), polyglycolide (PGA), poly(lactide-co-glycolide) (PLGA), polycaprolactone (PCL) belonging to the group of synthetic polymers, polydimethylsiloxane (PDMS), being the simplest member of the silicone polymer family, and chitin, chitosan, collagen of natural polymers are used with considerable degrees of success $[11,12]$.

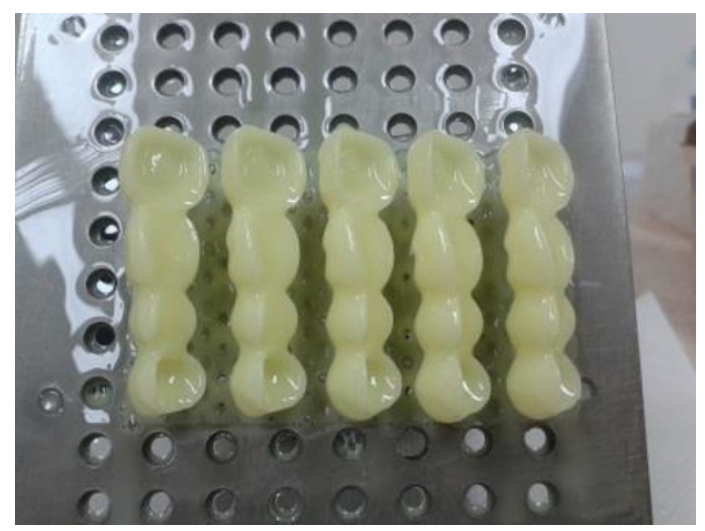

Fig. 1. 3D printed cast patterns of dental bridges [3] 
Polylactide [poly(lactic acid), PLA] belongs to the group of aliphatic polyesters (Fig. 2). The synthesis of PLA can be performed by the direct polycondensation of lactic acid or by the ring-opening polymerization of lactide (LA). LA possesses two chiral centers and can thus exist in three distinct diastereoisomers, namely, DD-, LL-, and DL-. Therefore, PLA shows stereochemical diversity. Depending on the synthesis conditions three forms of PLA with different properties can be obtained: poly(L-lactide) (PLLA), poly(DL-lactide) (PDLLA), and poly(D-lactide) (PDLA) [11, 12].

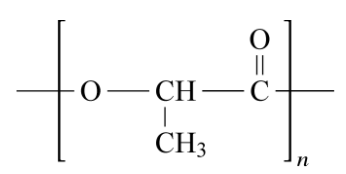

Fig. 2. Structure of polylactide

In general, PLA is a transparent thermoplastic polymer, quite stiff and brittle, and at the same time completely biodegradable. The disadvantage of PLA is its water absorption tendency, resulting from the presence of ester groups in its structure. The effect is greater with more amorphous polymer. However, the properties of PLA strongly depend on the composition of the repeat units ( $\mathrm{L}$ and $\mathrm{D}$ ) and their distribution along the polyester chain. PLA is not soluble in water, but it is soluble in dichloromethane (DCM) and dimethylformamide (DMF). The degradation rate of PLA depends on many factors, among the most important of which are: the molecular weight and the stereochemical composition, the type of end groups, the shape and the thermal history, the temperature and $\mathrm{pH}$ of the environment. In the first stage, the hydrolytic degradation (reverse process to condensation) with a decrease in the molecular weight of PLA occurs. The second stage is biological degradation under the influence of microorganisms that break down PLA oligomers into water and $\mathrm{CO}_{2}$. The time of PLA hydrolytic degradation in an inert environment at $37^{\circ} \mathrm{C}$ ranges from several months to 1 year. However, for the meso-polylactide form, biodegradation lasts up to several weeks. The great majority of the manufacturing and processing of PLA is carried out at $200^{\circ} \mathrm{C}$, ensuring a melt viscosity of less than $10^{3} \mathrm{~Pa} \cdot \mathrm{s}$. Under these conditions, PLA quite easily undergoes hydrolytic degradation and depolymerization processes. Ester bond breaking reactions are also possible $[11,12]$.

The high cost of the PLA synthesis limits its wider use, since the large-scale production of polylactide is too expensive for applications in the packaging industry $[4,5,7]$. Therefore, it is most often directed towards medical purposes as a material for the controlled drug release. Bioresorbable implants and surgical sutures, clamps, clips, surgical masks, dressings, compresses, medical staff clothing, pharmaceutical products and personal care materials are the main areas for PLA medical applications [8-10]. The great advantage of poly(lactic acid) and its copolymers results from the fact that its degradation products are natural metabolites. There is growing research interest in PLA, focused on reducing its production cost in order to expand the range of its applications, particularly in the packaging industry and the production of alternative fibers to nylon $[4,12]$. Although polylactide-based materials have been commonly processed into medical products by conventional techniques (e.g., casting, porogen leaching), PLA, its copolymers and composites are also increasingly often used in 3D printing technology [13, 14]. Breast-shaped poly(D,L)-lactide scaffolds fabricated by the melt extrusion were investigated for their potential in the long-term sustained regeneration of adipose tissue [15]. Poly-L-lactide copolymers such as poly(L-lactide- $c o$ - $\varepsilon$-caprolactone) and poly(L-lactide-co-glycolide) were considered as tubes for absorbable nerve guides and scaffolds for bone tissue engineering $[16,17]$. Different additive manufacturing (AM) technologies were used: solution extrusion and selective laser sintering, respectively.

The publication is an introduction to the wider research plan on the modification of polylactide in the context of its use as a filament in 3D printing technology. As a starting point, the structural and thermoanalytical analysis of two commercial filaments commonly used in the 3D printing technique was assumed. The determination of the temperature range in which PLA does not degrade is important in the context of the planned research work on its modification to improve the thermal and mechanical properties of PLA-based materials. The planned modification is aimed at a specific type of 3D printer dedicated to the production of detailed components for the automotive industry. The next part of the publication will present the research results on the resulting filament containing PLA.

\section{EXPERIMENTAL}

\subsection{Materials}

Two commercial polylactide (PLA) filaments from different sources were tested: 1 - blue (INK3.DE) and 2 - black (VAKIND). The PLA-based samples were parts of polymers rolls of circular cross-section measuring $1.75 \mathrm{~mm}$ in diameter.

\subsection{Thermogravimetric analysis (TG-DTG)}

Thermal analysis was performed using a Jota thermal analyzer. The examinations were carried out in open platinum crucibles using a sample mass ca. $10 \mathrm{mg}$ under an oxidizing atmosphere (synthetic air) (flow rate $40 \mathrm{ml} / \mathrm{min}$ ) and in the temperature range from $25^{\circ} \mathrm{C}$ to $1000^{\circ} \mathrm{C}$. The heating rate of the test sample was $10^{\circ} \mathrm{C} / \mathrm{min}$.

\subsection{Structural analysis by the transmission technique (FTIR)}

The structural tests were performed using the transmission technique (with $\mathrm{KBr}$ pellets) with the use of a Digilab Excalibur FTS $3000 \mathrm{Mx}$ spectrometer with the DTGS detector. The sample preparation for the FTIR technique required making pellets $(\phi 10 \mathrm{~mm})$. To receive them, the materials had to be finely ground to produce particles that were smaller than the wavelength of IR radiation $(5 \mu \mathrm{m})$. Then, the prepared PLA-based samples in the amount of $2 \mathrm{mg}$ were mixed with $200 \mathrm{mg}$ of powdered, pure and dry potassium bromide $(\mathrm{KBr})$. The pellets obtained by 
compressing the mixtures in a hydraulic press at 200 bar for 1 min were then placed in the measuring chamber of the spectrometer. The obtained spectrum of each sample was compared with the background spectrum (KBr). The spectrum was recorded by the Varian Resolution Pro program, within an infrared radiation range of $4000-400 \mathrm{~cm}^{-1}$, with a power of resolution of $4 \mathrm{~cm}^{-1}$. The interferograms consisted of 32 sample scans, which were averaged over one spectrum.

\subsection{Thermal analysis by diffuse reflectance technique (DRIFT)}

Diffuse reflectance technique for infrared analysis of PLA samples was performed by means of an attachment connected to the devices for temperature and water cooling system control. The temperature spectra was recorded in the range of $25-400^{\circ} \mathrm{C}$ in the wavenumber range of $4000-600 \mathrm{~cm}^{-1}$ with the set resolution of $8 \mathrm{~cm}^{-1}$. The interferograms consisted of 64 sample scans, which were averaged over one spectrum.

The infrared beam was focused by a series of mirrors on the surface of the sample, which was placed in a sample holder. Diffuse radiation through the powder was collected by other mirrors and sent to the detector. Preparation of the samples included grinding the tested materials in an agate mortar and mixing them with powdered $\mathrm{KBr}$ in an empirically selected proportion. The sample holder, a ceramic crucible, was placed inside a dome with zinc selenium ( $\mathrm{ZnSe}$ ) windows. As the infrared beam penetrates only the top $0.5-2.0 \mathrm{~mm}$ of the material, the lower half of the crucible was filled with pure $\mathrm{KBr}$ powder.

The data were registered under the conditions of increasing temperature in the atmosphere of oxygen. The recording of the spectra began $1 \mathrm{~min}$ after the pre-determined temperature was reached. The normalization of the spectra was performed by way of comparing the obtained spectrum with the background spectrum $(\mathrm{KBr})$.

\section{RESULTS AND DISCUSSION}

\subsection{TG-DTG analysis}

Figure 3 shows the TG-DTG results for polylactide samples. Thermal decomposition of both PLA1 sample (Fig. 3a) and PLA2 sample (Fig. 3b) started at the same moment (after reaching the temperature of $300^{\circ} \mathrm{C}$ ). The difference in the TG-DTG curves of the tested polymers indicates on better thermal stability of the PLA1 sample. Its thermal degradation occurred in the temperature range of $300-500^{\circ} \mathrm{C}$. The final weight loss was $99.03 \%$. The changes, under the influence of temperature, appeared more rapidly in the PLA2 sample. The polymer decomposition ended at $400^{\circ} \mathrm{C}$. Its weight loss was $99.29 \%$, so it was higher than the final PLA1 mass loss by $0.26 \%$. It can also be seen that between $300^{\circ} \mathrm{C}$ and $400^{\circ} \mathrm{C}$ the PLA1 TG curve is non-linear. Therefore, the nature of its degradation process is slightly more complex than the thermal decomposition of the second polymer (PLA2). a)

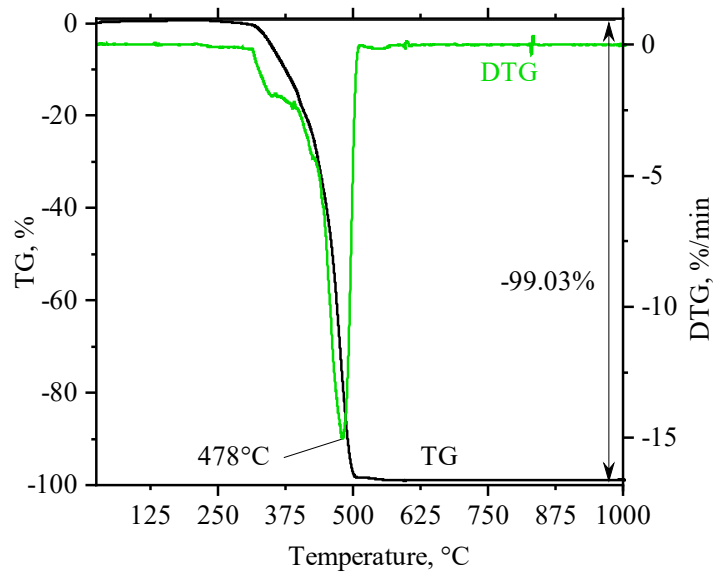

b)

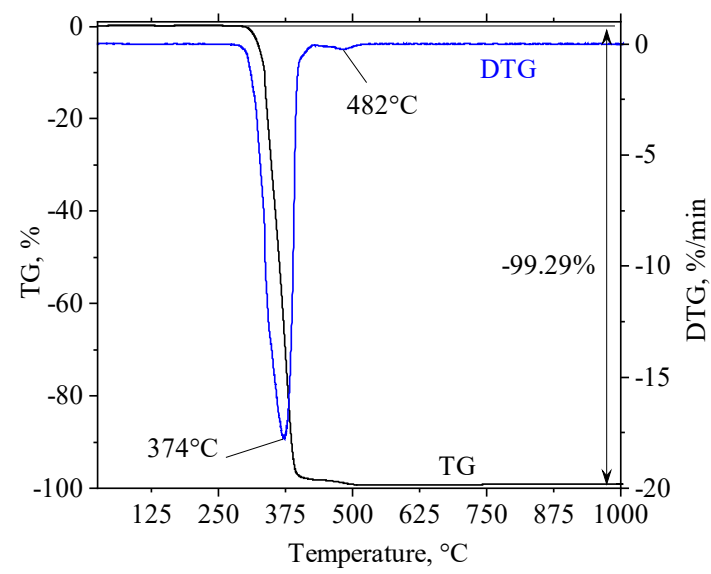

Fig. 3. TG-DTG curves of: a) PLA1; b) PLA 2

\subsection{Structural analysis}

FTIR spectra of PLA samples have been shown in Figure 4.

The absorption bands of low intensity in the wavenumber region of about $3500 \mathrm{~cm}^{-1}$ are typical of the free $\mathrm{O}-\mathrm{H}$ group $\left(\mathrm{H}_{2} \mathrm{O}\right)$. The maxima of the bands at $2925 \mathrm{~cm}^{-1}$, $2848 \mathrm{~cm}^{-1}$ (spectrum 1) and $2998 \mathrm{~cm}^{-1}, 2945 \mathrm{~cm}^{-1}$ (spectrum 2) are assigned to $\mathrm{C}-\mathrm{H}$ stretching vibrations.

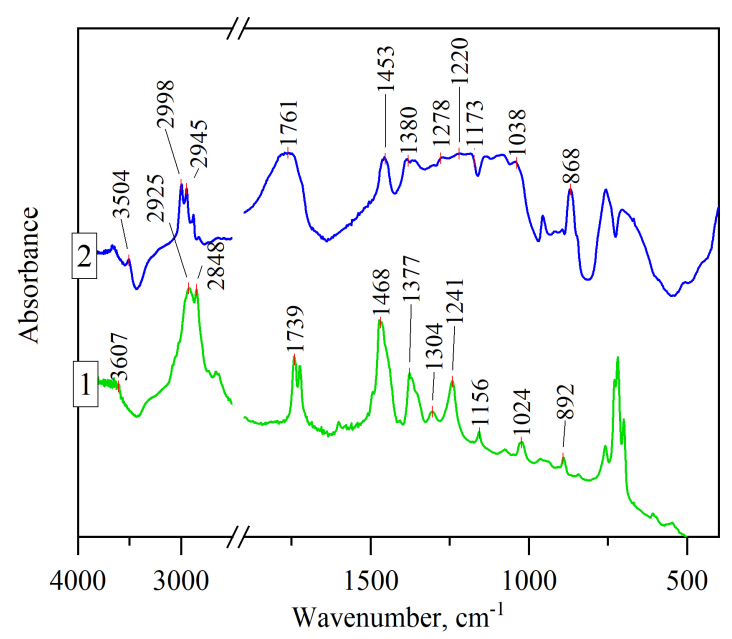

Fig. 4. IR spectra of: 1) PLA1; 2) PLA2 
Characteristic bands of polylacite functional groups can also be distinguished. The absorption bands observed in the range of wavenumber $1739-1761 \mathrm{~cm}^{-1}$ and $1156-1173 \mathrm{~cm}^{-1}$ correspond respectively to the stretching vibrations of $\mathrm{C}=\mathrm{O}$ and $\mathrm{C}-\mathrm{O}-\mathrm{C}$ groups. The noticeable differences in the bands related to, e.g., $\mathrm{C}=0$ bending vibrations $\left(1220 \mathrm{~cm}^{-1}\right.$ on spectrum 1 and $1241 \mathrm{~cm}^{-1}$ on spectrum 2), which can be seen in both spectra, may be the result of the presence of additives (dyes) in the samples.

Identified bands on IR spectra for a PLA samples are summarized in Table 1.

Table 1

Characteristic absorption bands on the IR spectra of PLA samples

\begin{tabular}{|c|c|c|c|}
\hline \multicolumn{2}{|c|}{ Sample } & \multirow{3}{*}{ Assignment } & \multirow{3}{*}{ Remarks } \\
\hline PLA1 & PLA2 & & \\
\hline \multicolumn{2}{|c|}{ Wavenumber, $\mathbf{c m}^{-1}$} & & \\
\hline 3504 & 3607 & $v-\mathrm{OH}$ & Band of free $\mathrm{OH}$ group (water) \\
\hline 2998 & 2925 & \multirow{2}{*}{$\begin{array}{l}v-\mathrm{C}-\mathrm{H} \\
v\left(\mathrm{CH}_{2}\right)\end{array}$} & \multirow{2}{*}{$\begin{array}{l}\text { Stretching vibrations } \\
\text { asymmetric and symmetric }\end{array}$} \\
\hline 2945 & 2848 & & \\
\hline 1761 & 1739 & $v_{s}-C=0$ & $\begin{array}{l}\text { Stretching vibrations } \\
\text { of carbonyl group }\end{array}$ \\
\hline 1453 & 1468 & $\beta\left(\mathrm{CH}_{3}\right)$ & In-plane bending vibrations \\
\hline 1380 & 1377 & \multirow{2}{*}{$\delta-\mathrm{CH}-$} & \multirow{2}{*}{$\begin{array}{l}\text { Deformation vibrations } \\
\text { asymmetric and symmetric }\end{array}$} \\
\hline 1278 & 1304 & & \\
\hline 1220 & 1241 & $-\mathrm{C}=0$ & Bending vibrations \\
\hline 1173 & 1156 & $v-\mathrm{C}-\mathrm{O}-$ & Stretching vibrations \\
\hline 1038 & 1024 & $v-\mathrm{OH}$ & Stretching vibrations \\
\hline 868 & 892 & $-\mathrm{C}-\mathrm{C}$ & Stretching vibrations \\
\hline
\end{tabular}

Figure 5 depicts the DRIFT temperature spectra obtained for the polylactide samples.

The determination of the structural changes occurring in PLA1 (Fig. 5a) and PLA2 (Fig. 5b) was carried out under the conditions of increasing temperature in the range of $25-500^{\circ} \mathrm{C}$. The DRIFT spectra were recorded in the middle infrared range of $4000-600 \mathrm{~cm}^{-1}$ by the technique of diffuse reflectance spectroscopy. In both spectra, the shape and position of the bands changes as the temperature increases. The intensity of certain bands also changes, some disappear completely. Moreover, new bands appear.

The characteristic peaks appearing on the DRIFT spectra in a region of low wavelength of the PLA1 sample (Fig. 5a) are: the $\mathrm{C}-\mathrm{O}-\mathrm{C}$ deformation vibrations which correspond to peaks at 730 and $928 \mathrm{~cm}^{-1}$ and the $\mathrm{C}-\mathrm{C}$ stretching vibrations at $1057 \mathrm{~cm}^{-1}$. The bands with maxima wavenumbers of 1361 and $1445 \mathrm{~cm}^{-1}$ can be attributed to $\mathrm{CH}_{3}$ (deformation) groups, while at $2924 \mathrm{~cm}^{-1}$ to $\mathrm{CH}_{3}$ (stretching) groups. The new band at $1584 \mathrm{~cm}^{-1}$ is assigned to ester group (COO). The sharp, strong peak at $1762 \mathrm{~cm}^{-1}$ corresponds to $\mathrm{C}=0$ vibrations. There is also a small $\mathrm{OH}$ peak at $3713 \mathrm{~cm}^{-1}$.
The changes in PLA1 structure (Fig. 5a) that appear with increasing temperature are mainly related to its progressive thermal degradation. Above $300^{\circ} \mathrm{C}$, in the wavelength range from 730 to $1584 \mathrm{~cm}^{-1}$, a gradual increase in the band intensity can be observed, especially in the area at $1240 \mathrm{~cm}^{-1}$. A similar tendency can be noticed in the case of bands with peaks at 1762 and $2924 \mathrm{~cm}^{-1}$. In these areas, the bands extension was also registered. At the same time (at the temperature of $300-400^{\circ} \mathrm{C}$ ), a new band appears with a maximum at $1584 \mathrm{~cm}^{-1}$, which can be attributed to $v_{\text {as }}(\mathrm{OCO})$ vibrations. This may indicate the formation of gaseous products, i.e. mixtures of carbon dioxide and oxygen gases.

The course of structural changes of PLA2 (Fig. 5b) is similar, except that shifts of maximum bands are observed and visible changes in the intensity of some bands are observed (increase in intensity at $400^{\circ} \mathrm{C}$ with a maximum of $1765 \mathrm{~cm}^{-1}$, $1093 \mathrm{~cm}^{-1}$ ). Bands not present in the DRIFT spectra of PLA1 have also been observed - with a maximum of $1190 \mathrm{~cm}^{-1}$ and $864 \mathrm{~cm}^{-1}$, which are likely to be associated with different additives (e.g. dyes) in the filament.

a)

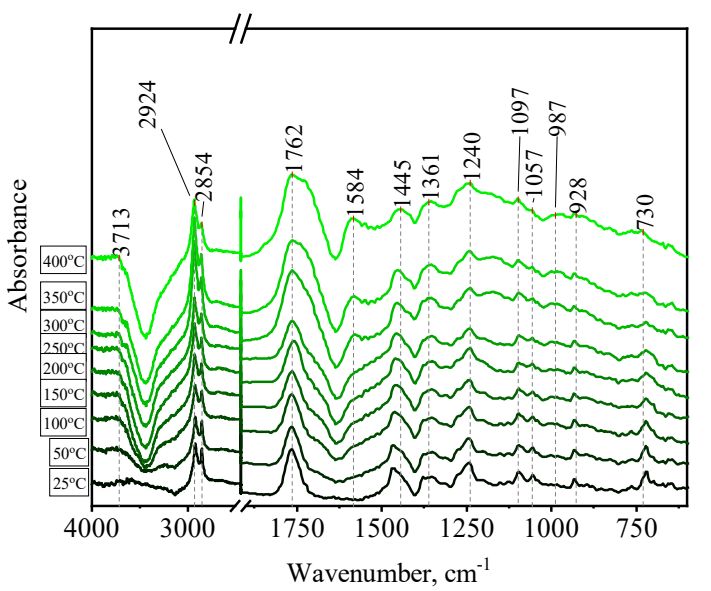

b)

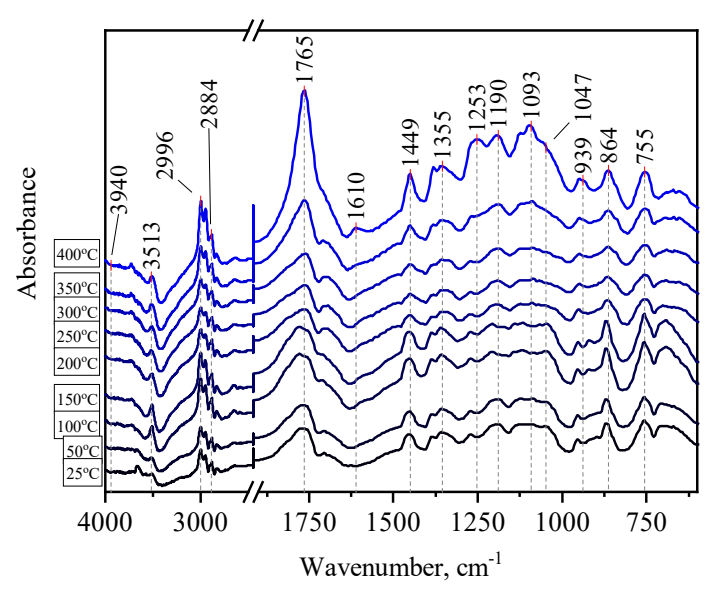

Fig. 5. DRIFT spectra recorded for the a) PLA1; b) PLA2 sample in the temperature range of $25-400^{\circ} \mathrm{C}$

\section{CONCLUSIONS}

The complex thermoanalytical analysis (FTIR, DRIFT, TG-DTG) allowed the determination of the temperature range in which the initial commercially available polylactide does not undergo thermal degradation but only reversible transformations, and thus does not lose its functional properties. 
On the basis of the obtained test results, it can be stated that both PLA samples are thermally stable in the temperature range $25-300^{\circ} \mathrm{C}$. Thus, the operating temperature of a typical 3D printer where the processing of polylactide takes place, is not exceeded (extrusion temperature is not exceeded). In addition, the information obtained is important in terms of optimizing the conditions of its processing, including the use of 3D printing technology for the production of details for the automotive industry.

\section{REFERENCES}

[1] Kaziunas France A. (2014). Świat druku 3D. Przewodnik. Gliwice: Wydawnictwo Helion.

[2] Dodziuk H. (2019). Druk 3D/AM. Zastosowania oraz skutki spoteczne i gospodarcze. Warszawa: Wydawnictwo Naukowe PWN.

[3] Dikova T., Dzhendov D., Bliznakova K. \& Ivanov D. (2016). Application of 3D printing in manufacturing of cast patterns. VII $^{\text {th }}$ International Metallurgical Congress, 9-12 June 2016, Ohrid, Macedonia.

[4] Manas C. \& Salil R. (2008). Industrial polymers, specialty polymers and their applications. Boca Raton, USA: CRC Press.

[5] Syrek H. (2013). Zastosowanie drukarek 3D do wytwarzania modeli woskowych $\mathrm{w}$ procesie odlewania metodą traconego wosku. Nafta-Gaz, 69(12), 929-935.

[6] Przybytek A., Kucińska-Lipka J. \& Janik H. (2016). Thermoplastic elastomer filaments and their application in 3D printing. Elastomery, 20(4), 32-39.

[7] Sasimowski E. (2015). Przyrostowe metody wytwarzania elementów z tworzyw polimerowych. Przetwórstwo Tworzyw, 21(4), 349-354.

[8] Sarecka-Hujar B., Ostróżka-Cieślik A. \& Banyś A. (2016). Innowacyjne technologie w medycynie i farmacji. Acta Bio-Optica et Informatica Medica. Inżynieria Biomedyczna, 22(1), 9-17.
[9] Lee V., Singh G., Trasatti J.P., Bjornsson C., Xu X., Tran T.N., Yoo S.S., Dai G. \& Karande P. (2014). Design and fabrication of human skin by three-dimensional bioprinting. Tissue Engineering: Part C: Methods, 20(6), 473-484. Doi: 10.1089/ten.TEC.2013.0335.

[10] Kusaka M., Sugimoto M., Fukami N., Sasaki H., Takenaka M., Anraku T., Ito T., Kenmochi T., Shiroki R. \& Hoshinga K. (2015). Initial experience with a tailor-made simulation and navigation program using a 3-D printer model of kidney transplantation surgery. Transplantation Proceedings, 47(3), 596-599. Doi: 10.1016/j.transproceed.2014.12.045.

[11] Florjańczyk Z. \& Penczek S. (1995). Chemia polimerów, Vol. 1: Makroczasteczki i metody ich otrzymywania. Warszawa: Oficyna Wydawnicza Politechniki Warszawskiej.

[12] Rabek J.F. (2008). Współczesna wiedza o polimerach. Warszawa: Wydawnictwo Naukowe PWN.

[13] Woźna A. (2012). Struktura kompozytów bioresorbowalnych wytworzonych z zastosowaniem generatywnej metody laserowej. Modelowanie Inżynierskie, 14(45), 134-138.

[14] Poh P.S.P., Chhaya M.P., Wunner F.M., De-Juan-Pardo E.M., Schilling A.F., Schantz J.T., van Griensven M. \& Hutmacher D.W. (2016). Polylactides in additive biomanufacturing. Advanced Drug Delivery Reviews, 107, 228-246.

[15] Chhaya M.P., Melchels F.P.W., Holzapfel B.M., Baldwin J.G. \& Hutmacher D.W. (2015). Sustained regeneration of high-volume adipose tissue for breast reconstruction using computer aided design and biomanufacturing. Biomaterials, 52, 551-560.

[16] Thapsukhon B., Thadavirul N., Supaphol P., Meepowpan P., Molloy R. \& Punyodom W. (2013). Effects of copolymer microstructure on the properties of electrospun poly(L-lactide- $c o$ - $\varepsilon$-caprolactone) absorbable nerve guide tubes. Journal of Applied Polymer Science, 130(6), 4357-4366.

[17] Simpson R.L., Wiria F.E., Amis A.A., Chua C.K., Leong K.F., Hansen U.N., Chandrasekaran M. \& Lee M.W. (2008). Development of a $95 / 5$ poly(L-lactide-co-glycolide)/hydroxylapatite and $\beta$-tricalcium phosphate scaffold as bone replacement material via selective laser sintering. Journal of Biomedical Materials Research Part B: Applied Biomaterials, 84B(1), 17-25. 